\title{
Genome engineering via homologous recombination in mouse embryonic stem (ES) cells: an amazingly versatile tool for the study of mammalian biology
}

\author{
CHARLES BABINET and MICHEL COHEN-TANNOUDJI \\ Unité de Biologie du Développement, CNRS URA 1960, Institut Pasteur, 75015 Paris, France \\ Manuscript received on May 16, 2001; accepted for publication on May 23, 2001; \\ presented by Vivaldo Moura Neto
}

\begin{abstract}
The ability to introduce genetic modifications in the germ line of complex organisms has been a long-standing goal of those who study developmental biology. In this regard, the mouse, a favorite model for the study of the mammals, is unique: indeed not only is it possible since the late seventies, to add genes to the mouse genome like in several other complex organisms but also to perform gene replacement and modification. This has been made possible via two technological breakthroughs: 1) the isolation and culture of embryonic stem cells (ES), which have the unique ability to colonize all the tissues of an host embryo including its germ line; 2) the development of methods allowing homologous recombination between an incoming DNA and its cognate chromosomal sequence (gene "targeting"). As a result, it has become possible to create mice bearing null mutations in any cloned gene (knock-out mice). Such a possibility has revolutionized the genetic approach of almost all aspects of the biology of the mouse. In recent years, the scope of gene targeting has been widened even more, due to the refinement of the knock-out technology: other types of genetic modifications may now be created, including subtle mutations (point mutations, micro deletions or insertions, etc.) and chromosomal rearrangements such as large deletions, duplications and translocations. Finally, methods have been devised which permit the creation of conditional mutations, allowing the study of gene function throughout the life of an animal, when gene inactivation entails embryonic lethality. In this paper, we present an overview of the methods and scenarios used for the programmed modification of mouse genome, and we underline their enormous interest for the study of mammalian biology.
\end{abstract}

Key words: embryonic stem cells (ES), genome, gene "targeting", knock-out mice, conditional mutations.

\section{INTRODUCTION}

For decades geneticists have understood the interest of studying mutations that, through the genotype they generate, reveal the function of the genes in which they are produced. However, in complex organisms such as the mouse, which is a model of choice for the study of mammals, for many years the

Correspondence to: Dr. C. Babinet

E-mail: chbabi@pasteur.fr / m_cohen@pasteur.fr mutations obtained were limited to those observed randomly during breeding and were essentially visible modifications in phenotype (color of the fur, morphology, behavior, etc.), and few developmental mutations were observed in this way. Therefore the possibility of creating deliberate and controlled genetic modifications was a dream anticipated by Avery et al. (1944), more than fifty years ago. In their seminal study using bacteria, these authors demonstrated that DNA is the chemical support for 
hereditary characters: "Biologists have long attempted by chemical means to induce in higher organisms predictable and specific changes which thereafter could be transmitted in series as hereditary characters". The aim of our paper is to show how this dream has become reality over the past twenty years, through the development of methods that modify the genetic make-up of the mouse (see Table I). The creation of mice with genetic modifications programmed by the investigator has revolutionized the study of almost all the biological aspects of this animal and its various systems (immune, nervous, hematopoietic, etc.) (for a review, see Capecchi 1989). Moreover, this could lead to the creation of murine models for human genetic diseases (Smithies 1993), precious for studying their physiopathology and eventually for the development of appropriate therapies. As we will see later, this was made possible by the breakthrough of two different approaches: one led to the isolation in vitro of remarkable cells: embryonic stem (ES) cells (Gardner and Brook 1997); the other permitted identification, in higher eukaryote cells, of the conditions required for homologous recombination between incoming DNA and the homologous sequence in the chromosome (Smithies et al. 1985, Wong and Capecchi 1986).

\section{EMBRYONIC STEM CELLS: FABULOUS VEHICLES FOR THE CREATION OF MUTANT MICE}

In 1981, two laboratories reported the isolation, from the culture of early mouse embryos, of cell lines with the properties of pluripotent embryonic cells (Martin 1981, Evans and Kaufman 1981) (see Table II). These cells, called Embryonic Stem (ES) cells, after injection into a young embryo were capable of colonizing all its tissues including the germ line, thus giving birth to chimeras. The ES cell genotype cells could then be "recycled" in vivo and transmitted to future generations. Following this, it was demonstrated that these cells could be genetically modified in vitro, by introduction of a transgene, for example, but also that the corresponding transgenic mice could be obtained (Gossler et al.
1986, Robertson et al. 1986) (see Fig. 1). Thus a totally new method for obtaining transgenic mice was born, considerably widening the possibility of "classical" transgenesis by microinjection of DNA in the zygote. Indeed, it became possible for the investigator to use procedures selecting rare genetic modifications in the ES cells and to obtain the corresponding mutant mice.

\section{HOMOLOGOUS RECOMBINATION IN ES CELLS: CREATION OF “KNOCK OUT” MICE}

Studies conducted in the eighties, particularly by the groups of Smithies and Capecchi, had demonstrated that mammalian cells have the enzymatic apparatus necessary for recombination between an incoming DNA and the homologous sequence present in situ in the chromosomes, even if this was relatively rare compared with the random integration of this same DNA (Smithies et al. 1985, Wong and Capecchi 1986). At first, these results were used by these authors to create - or correct - null mutations in the hprt gene (Doetschman et al. 1987, Thomas and Capecchi 1987): these mutations can be selected directly after transfection of the targeted vector carrying the required mutation, through addition of drugs in the culture medium. Despite the generally variable and low frequency of homologous recombination events, these experiments were later extended to genes the null mutations of which cannot be selected, using various approaches based either on selection or on screening techniques (see Fig. 2). Today, hundreds of genes have been invalidated in this manner and corresponding mutant mice have been created (Tbase 2001). Analysis of the phenotypes generated by these mutations has cast light on the function of the genes concerned. In certain cases, analysis also allowed to reveal the influence of genetic background on the expression of a given mutation (for a review, see Banbury Conference 1997), or to investigate the eventual genetic relationships between genes of the same family (for reviews, see Rudnicki and Jaenisch 1995, Horan et al. 1995). 


\section{TABLE I}

A few milestones in the history of programmed mutagenesis in vivo in the mouse.*

\begin{tabular}{ll}
\hline $1976^{* *}$ & $\begin{array}{l}\text { Transgenic mice by retroviral infection of embryos } \\
\text { during cleavage. } \\
\text { Transgenic mice by microinjection of DNA in the } \\
\text { pronucleus of the zygote. }\end{array}$ \\
1981 Establishment of ES cell lines. \\
1986 & $\begin{array}{l}\text { Transgenic mice via the generation of germline } \\
\text { chimeras with genetically modified ES cells. }\end{array}$ \\
1987 & $\begin{array}{l}\text { First experience of programmed mutagenesis: } \\
\text { ES cells carrying a null mutation in the HPRT gene } \\
\text { are obtained. }\end{array}$ \\
& $\begin{array}{l}\text { First mutant mice obtained by homologous } \\
\text { recombination in ES cells. } \\
\text { Creation of chromosomal rearrangements. Creation of } \\
\text { conditional mutations. }\end{array}$ \\
\hline
\end{tabular}

*Readers interested in the studies surrounding this history can consult the special issue of the International Journal of Developmental Biology (vol. 42(7), 1998) for the appropriate references. $* *$ These transgenic mice result from gene addition (microinjection of DNA in the zygote pronucleus and retroviral infection of cleavage stage embryos) and are not the subject of this paper. Interested readers can consult the book Transgenic Animals: generation and use, edited by Louis-Marie Houdebine, Harwood Academic Publishers, 1997.

TABLE II

Mouse Embryonic Stem cells.

\section{Properties}

- Pluripotent

- Unlimited self-renewal in vitro with maintenance of the pluripotency. Selection of rare genetic modifications possible.

- Differentiation in vitro into different cell types

- Colonization of the tissues of a host embryo including its germ line. Transfer to the animal of the genetic modifications introduced in the ES cells

\section{Modifications created by homologous recombination}

- $\quad$ Null mutations (knock-out)

- Subtle mutations (point mutations, microdeletions, microadditions, etc)

- Chromosomal rearrangements (deletions, inversions, translocations)

- Conditional mutations 


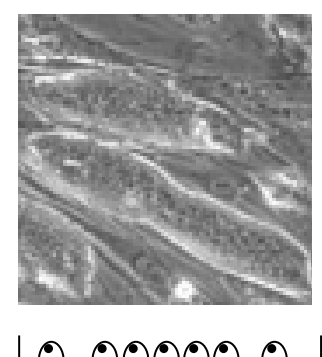

ES cells
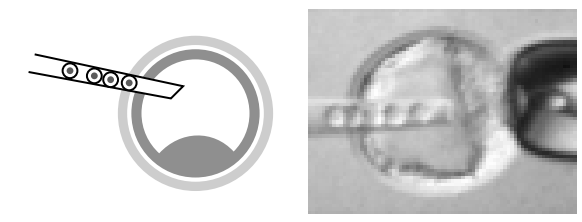

blastocyst's microinjection

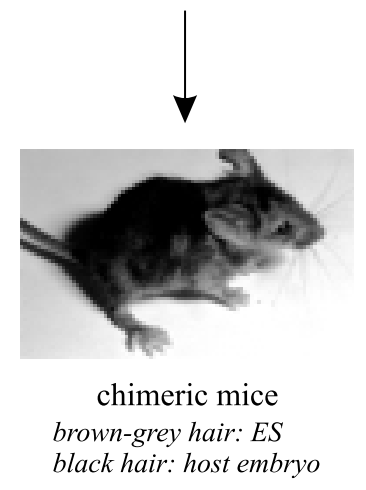

Analysis of the phenotype induced by the genetic modification in chimeric, heterozygous or homozygous mice
DNA transfer (retroviruses, transgene, targetting vector, ...)

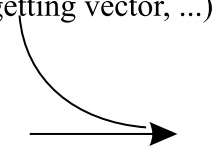

ES cells
Ln คmp ma

genetically modified

Selection and isolation of a clone with the desired genetic modification

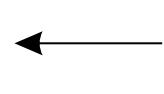

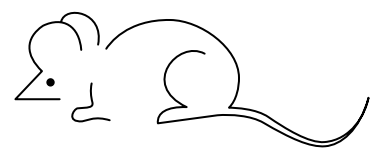

normal mouse

Fig. 1 - The different stages in the creation of genetically modified mice via ES cells.

\section{A REFINEMENT OF THE KNOCK-OUT: THE ..... KNOCK-IN}

An interesting variation of the targeting vectors for obtaining null mutations can be obtained by the introduction of a given cDNA in frame with the coding sequence of the targeted gene, (Fig. 2). Following homologous recombination with the chosen target gene, the modified allele expresses the cDNA inserted in replacement of the endogenous gene. The choice of the cDNA obviously depends on the aim of the research. For example, this might be the coding sequence of a reporter gene such as E. coli LacZ gene encoding $\beta$-galactosidase, the activity of which is easily traceable even at the single cell level. The expression of $\beta$-galactosidase mimics the expression of the targeted gene. This is precious for specifying its expression pattern (Colucci-Guyon et al. 1994), but can also be useful for monitoring the fate of cells that normally express the targeted gene, in the context of an animal carrying the mutation in 
a)

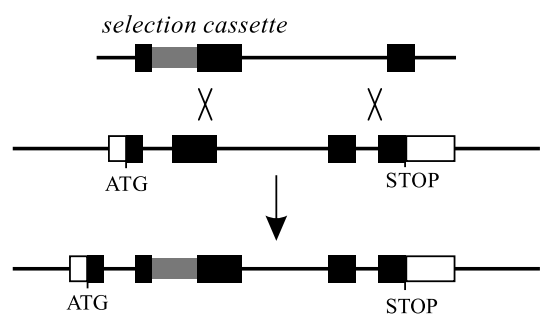

Knock-out: gene disruption by selection cassette insertion b)

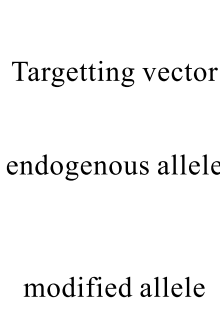

gene of interest , immortalizing gene, paralogue, mutated $c D N A, \ldots)$

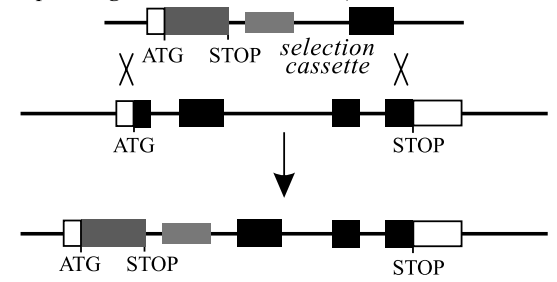

Knock-in: gene of interest expressed in place of the targetted gene

Fig. 2 - General principle of homologous recombination. a) 'Knock-out'. The targeting vector includes a selection cassette inserted in an exon (black rectangle: coding region; white rectangles: non coding regions) and surrounded by regions of homology with the target gene. Recombination with the endogenous gene occurs within these homologous sequences and results in the creation of a null allele in which disruption of the gene is induced by insertion of the selection cassette. b) "Knock-in". In this variant, besides invalidation of the target gene, a gene of interest is introduced in the locus. Following homologous recombination, the gene of interest is placed under the control of the promoter and regulatory sequences of the target gene and is therefore expressed in place of the target gene.

the homozygous state (Schneider-Maunoury et al. 1993, Tajbakhsh et al. 1996). Another particularly interesting use of the knock-in strategy concerns the genes belonging to a multigenic family, with differing expression patterns, and the invalidation of which leads to contrasting phenotypes. Do the proteins coded by the related genes have equivalent function? A positive reply to this would indicate that the change in expression profile is at the origin of the phenotypes observed and not a differing function of the proteins coded by these genes. According to studies published to date (Table III and Hanks et al. 1995, 1998, Wang and Jaenisch 1997, Saga 1998, Acampora et al. 1999, Geng et al. 1999, Suda et al. 1999), it is generally this type of situation that is observed, which underlines the importance of the gene regulating regions acting as targets for evolution and functional diversification.

\section{FROM NULL TO SUBTLE MUTATIONS}

If null mutations are a potent instrument in genetic analysis, it is clear that other more subtle types of mutations (point mutations, small deletions or insertions) may also be very useful. On the one hand, they allow to refine the functional analysis of a gene (by changing the amino acid in a particular domain of the protein and observing the effects induced, for example) and on the other hand they also permit creation of murine models of genetic diseases in man: the latter are rarely generated by null mutations (for example, $60 \%$ of mutations leading to cystic fibrosis in man are of $\Delta \mathrm{F} 508$ type (Kerem et al. 1989), i.e., corresponding to the deletion of a single amino acid, phenylalanine, in the CFTR (Cystic Fibrosis Transmembrane Receptor) protein. When mutant alleles of this type are created, it is essential to remove the selection sequences that might interfere with the regulation of the expression of the targeted gene or adjacent gene. Such an interference has been demonstrated in several studies (Fiering et al. 1999) and, in some cases can lead to hypomorph mutations by the introduction the selection sequence in the 5 ' region of a gene (Meyers et al. 1998). Several strategies can be used to create what one could call "clean" mutations (mutant allele without foreign sequences) (Moore et al. 1998, for a review see Cohen-Tannoudji and Babinet 1998). We describe two of these in Figure 3; however, the one which uses the Cre/loxP system is particularly interesting, because, as we will see, it is versatile over and 


\section{TABLE III}

Some examples of knock-in.

\begin{tabular}{|c|c|c|c|}
\hline Gene inserted $\rightarrow$ gene disrupted & Knock-out phenotype & Knock-in phenotype & Ref. \\
\hline $\begin{array}{l}\text { Cyclin } E \rightarrow \text { Cyclin DI } \\
\text { (Proteins implicated in cell } \\
\text { cycle control) }\end{array}$ & $\begin{array}{l}\text { Neurological defects } \\
\text { Abnormalities of the } \\
\text { retina and mammary } \\
\text { tissue }\end{array}$ & $\begin{array}{l}\text { Complete restoration of } \\
\text { a normal phenotype }\end{array}$ & $\begin{array}{l}\text { Gent et al. } \\
1999\end{array}$ \\
\hline $\begin{array}{l}\text { Otx } 2 \rightarrow \text { Otxl } \\
\text { (homeodomain transcription } \\
\text { factors) }\end{array}$ & $\begin{array}{l}\text { Epilepsy } \\
\text { Dorsal telencephalic } \\
\text { cortex and vision and } \\
\text { audition system } \\
\text { abnormalities }\end{array}$ & $\begin{array}{l}\text { Suppression of epilepsy } \\
\text { and defects of } \\
\text { corticogenesis but } \\
\text { internal ear abnormalities } \\
\text { maintained }\end{array}$ & $\begin{array}{l}\text { Suda et al. } \\
1999\end{array}$ \\
\hline Otx $1 \rightarrow$ Otx 2 & $\begin{array}{l}\text { Abnormal gastrulation } \\
\text { At E6, absence of } \\
\text { forelimb structure }\end{array}$ & $\begin{array}{l}\text { Gastrulation normal } \\
\text { Forelimb structures } \\
\text { normal at E7-E8, but } \\
\text { loss of regionalisation of } \\
\text { structures before E9* }\end{array}$ & $\begin{array}{l}\text { Acampora et } \\
\text { al. } 1999\end{array}$ \\
\hline $\begin{array}{l}\text { Myogenin } \rightarrow \text { Myf5 } \\
\text { (transcription factors } \\
\text { implicated in myogenic } \\
\text { differentiation) }\end{array}$ & $\begin{array}{l}\text { Malformation of the } \\
\text { thorax } \\
\text { Prenatal lethality }\end{array}$ & $\begin{array}{l}\text { Complete restoration of } \\
\text { a normal phenotype }\end{array}$ & $\begin{array}{l}\text { Wang and } \\
\text { Jaenisch } 1997\end{array}$ \\
\hline $\begin{array}{l}\text { Mesp1 } \rightarrow \text { Mesp } 2 \\
\text { (b-HLH type transcription } \\
\text { factor) }\end{array}$ & $\begin{array}{l}\text { Prenatal death } \\
\text { Absence of somatic } \\
\text { segmentation } \\
\text { Skeletal defects }\end{array}$ & $\begin{array}{l}\text { Complete restoration of } \\
\text { a normal phenotype }\end{array}$ & Saga 1998 \\
\hline $\begin{array}{l}E n 2 \rightarrow E n 1 \\
\text { (homeodomain transcription } \\
\text { factor) }\end{array}$ & $\begin{array}{l}\text { Prenatal death } \\
\text { Absence of } \\
\text { posterior/mid-brain } \\
\text { region } \\
\text { Limb abnormalities }\end{array}$ & $\begin{array}{l}\text { Disappearance of brain } \\
\text { defects but maintenance } \\
\text { of the limb } \\
\text { abnormalities }\end{array}$ & $\begin{array}{l}\text { Hanks et al. } \\
1995 \\
\text { Hanks et al. } \\
1998\end{array}$ \\
\hline
\end{tabular}

*This loss is due to the fact that the OTX2 protein appears necessary for the regulation of the expression of the otx 2 gene. In $O t x 1 \rightarrow$ Otx 2 mutants, the otx 2 gene (and therefore the production of the OTX1 protein) is not induced in the anterior neural plaque. E: day of embryonic development.

above obtaining "clean" mutations (for a review, see Sauer 1998). The Cre protein is a recombinase identified in the $\mathrm{P} 1$ bacteriophage, which reacts when it recognizes a sequence of 34 base pairs (called $\operatorname{lox} P$ ) in a segment of DNA (Kilby et al. 1993) (see Fig. 4A-B). When two loxP sites are oriented in the same direction, the Cre recombinase induces the deletion of the DNA segment placed between them. Conversely, if the loxP sites are oriented in opposite direction, recombination induces its inversion (see Fig. 4C). It should be noted that Cre recombinase activity does not require a DNA co- 
a)

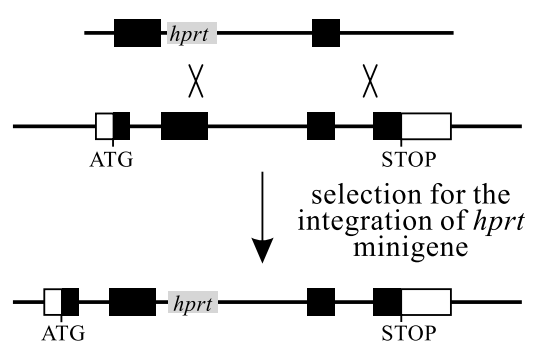

b)
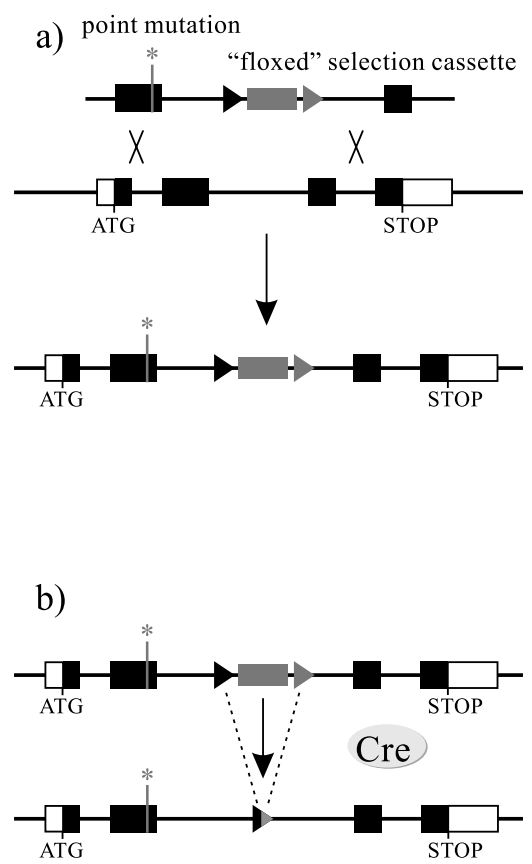

Cre/loxP system

Fig. 3 - "Clean" mutations. The persistence in a modified allele of a selection cassette with its own promoter and regulatory sequences may affect the target locus and surrounding loci. Creation of subtle mutations (point mutations, small deletions and insertions, ...) therefore requires elimination of the selection cassette. The two strategies most used to create this type of modifications are presented in this figure. Upper panels: the double replacement strategy. This approach requires the use of hprt-ES cell lines. The first step (A) consists in introducing a cassette expressing the hprt gene in the target gene. The recombinant cells (hprt+) are selected in the presence of HAT. In the second step (B), these cells are transfected with a replacement vector presenting a subtle mutation and devoid of a selection cassette. The homologous recombination event results in the loss of the hprt expression cassette, an event selected in the presence of 6-TG. The use of other replacement vectors carrying different modifications permits the rapid creation of several alleles for the same target gene. Lower panels: use of the Cre/loxP system (see Fig. 4). In the first step (C), the target gene is modified by a target vector with a subtle mutation and a "floxed" selection cassette, i.e. surrounded by 2 loxP sites in the same orientation. Then (D) the transient expression of Cre recombinase in the recombinant cells induces deletion of the selection cassette. Apart from the desired subtle modification, only one loxP site of $34 \mathrm{pb}$ persists in the final modified allele. The position of this loxP site is chosen so that it does not interfere with the expression of the target gene (generally in an intron).

factor or particular topology. Moreover, it is active in the eukaryote cells (Sauer and Henderson 1988). As is shown in Figure 3, these properties of the Cre/ loxP system could be used for the creation of alleles carrying "subtle" and "clean" mutations. At the end of this scenario, the muted allele retains a loxP site; however, no indication of an interference of this site with genetic expression has ever been demonstrated.

\section{DELETIONS VIA TARGETING IN THE ES CELLS: TOWARDS GLOBAL GENETIC ANALYSIS OF THE MOUSE GENOME}

Directed mutagenesis via ES cells is, as we have seen, a precious method for analysis of gene function. However this approach is limited to known and cloned genes. In a perspective of global functional analysis of the mouse genome, this inverse genetic approach must be completed by strategies that not 
only accumulate mutations but also localize them precisely. Thus corresponding genes can eventually be identified and cloned and then be used for targeted mutagenesis.

Over the past fifteen years, highly effective methods of chemical mutagenesis have been obtained which result in high-rate and random introduction of mutations in the mouse genome: the use of N-ethyl-N-nitrosourea (ENU) (Bode 1984), for a review, see Brown and Peters 1996), a potent mutagenic agent, leads, in the male mouse, to a mutation in a given gene in one gamete out of 700 (which is equivalent to a per locus mutation of around 1.5 $\mathrm{x} 10^{-3}$ and is very high). In general, the effect of ENU results in the creation of point mutations. Once the males have been treated by ENU and therefore carry mutations in their spermatogonia, an approach is needed to identify and collect these mutations. This would be made easier, in the case of recessive mutations, if one disposed of discrete deletions throughout the genome: the crossing between mice carrying a deletion in a given region and those carrying mutations induced by ENU should facilitate, the localization and the identification of the gene(s) responsible for the phenotype obtained, due to functional haploidy of the deleted region. This type of scenario, the interest of which has been clearly demonstrated in Drosophila, is difficult to apply to the mouse because of the relative rarity of deletions reported in this animal. In this context, targeting by homologous recombination in ES cells combined with the properties of the Cre/loxP system opens new opportunities ( for a review, see Justice et al. 1997) (Fig. 4C-D). This strategy was validated in 1995 when mice carrying deletions of several centimorgans (cM) were obtained (Ramirez-Solis et al. 1995). Using a different scenario, You et al. (1997) obtained deletions of varying length around a given locus. In the future, a collection of deletions could be accumulated and used, in combination with ENU mutagenesis, for long-term projects of global functional analysis of the mouse genome. The constant extension of genetic maps of the mouse and man should permit to analyse more specifically genomic regions which would be rich in genes and/or thought to be candidates for human genetic diseases.

\section{CHROMOSOMAL REARRANGEMENTS MADE EASIER BY THE EXPRESSION OF CRE IN THE MALE GERM LINE}

The recent generation of transgenic mice expressing Cre in the male germ line has simplified the process permitting the creation of chromosomal rearrangements in the mouse, by conducting part of the operations directly in vivo. Indeed, transgenic mice with an Sycp1-Cre fusion gene (in which the regulatory sequences of Sypcl coding for protein 1 of the synaptosomal complex control Cre protein expression), express the Cre protein in a specific manner during the pro-phase of the first meiotic division of male germ line cells, at a time when the chromosomal pairing starts and crossing-over is therefore facilitated (Vidal et al. 1998). If one crosses mice carrying loxP sites on chromosomes homologous with the latter, one obtains, in double-transgenic males issued from this crossing, spermatozoa containing deletions or duplications of the genomic region situated between the loxP sites (Figure 4D). Potentially, this approach is a strong tool for the functional analysis of complex genomic regions: for example, the question of functional significance of the clustering of Hox genes into complexes can be determined by varying their number or their position in these complexes (Herault et al. 1998).

\section{CONDITIONAL MUTAGENESIS: A NEW DIMENSION OF FUNCTIONAL GENOME ANALYSIS}

\section{A) The Cre/LoxP system: Targeting of Cre by A FUSION TRANSGENE}

We have emphasized the interest for the functional analysis of the genome of programmed creation of mice carrying various genetic modifications (null mutations, discrete mutations, chromosomal rearrangements, etc). However, these situations in which mutated mice carry the mutation in all their cells have their limitations in particular for two reasons: (1) in cases in which the mutation provokes embryonic lethality in the homozygous state (an ex- 
treme case is when mutation leads to cell death), it is impossible to study the eventual function of the gene beyond the time of embryonic letality and consequently during adulthood; (2) a gene may have a wide expression and its invalidation provoke a complex phenotype affecting multiple tissues. To simplify analysis in this case it would be interesting to create mice expressing the mutation in only one or the other of these tissues.

In an effort to overcome these limitations of programmed mutagenesis in vivo, in recent years different teams tried to develop strategies in which the expression of a mutation would be rendered conditional (for a review, see Gu et al. 1994, CohenTannoudji and Babinet 1998). These strategies are based on the remarkable properties of the Cre/loxP system. The first step (see Fig. 5) consists in creating mice carrying alleles in which two loxP sites surround an essential part of the gene to be studied, without disrupting its activity, by placing them for example in the introns (we subsequently call these alleles "flloxed" alleles). In the case of a gene whose null mutations are letal in the homozygous state, it is necesssary to verify that the mice homozygous for the floxed allele are viable. These mice are then crossed with a transgenic mouse expressing the Cre recombinase in a particular cell type, using appropriate regulatory sequences in the transgene (the Cre recombinase promotes the deletion of the sequences located between the loxP sites and induces a null mutation in the cell type in which the transgene is expressed). This strategy is powerful since it not only avoids the embryonic lethality produced when all the embryo cells carry the mutation, but also allows to address the effect of this mutation in any tissue, so long as a line of transgenic mice expressing protein Cre in the tissue concerned is available (Table IV, Tsien et al. 1996, Shibata et al. 1997, Harada et al. 1999, Kulkarni et al. 1999, Xu et al. 1999).

\section{B) INDUCIBLE SYSTEMS}

Supplementary refinement consists in controlling induction of the mutation, not only in space as ex- plained above but also in time. To that end, protein Cre is expressed in the form of a fusion protein with the ligand binding domain of a steroid receptor (LBD) (Kellendonk et al. 1996, Feil et al. 1996); this fusion protein has no Cre activity (see Fig. 6). However, in the presence of an appropriate ligand, a change in conformation is produced that restores $\mathrm{Cre}$ activity. Thus, in transgenic mice carrying the two floxed alleles of the gene concerned and the transgene expressing the fusion protein LBD/Cre under the control a promoter functioning in a given tissue, induction of a null mutation can be obtained by injection, at a given time, of the appropriate ligand (Fig. 6). An interesting alternative to the use of LBD/Cre fusion proteins was recently demonstrated by the injection, in a tissue of a mouse carrying the "floxed" gene, of an adenoviral vector capable of expressing Cre: indeed, only the cells infected locally by the virus expressed the mutation (Table IV and Shibata et al. 1997). To end our brief description of the approaches developed to obtain conditional mutations, one must mention the possibility of controlling the recombinase expression by using systems that induce or inhibit the transcription of a reporter gene. The most documented system uses the operator/repressor properties of the bacterial operon, tetracycline (tet) (Baron et al. 1999). This comprises on the one hand a reporter gene controlled by a minimal promoter linked to a concatermer of the tet operator (tet $O$ ) sequences, and on the other hand a gene expressing a fusion protein between the repressor tetR and the activation domain of the VP16 protein (protein tTA). In the presence of tetracycline the fusion protein cannot bind to the $t e t O$ sequences and the reporter gene is not expressed. In the absence of tetracycline, the fusion protein can bind and the reporter gene is expressed. An alternative is to use a fusion protein constructed with a mutant version of the tetR repressor which can only bind to the tet $O$ sequences in the presence of tetracycline: activation of the reporter gene can therefore be induced by addition of the antibiotic. The proof of the transcriptional control obtained using this binary system has been demonstrated in cell cultures and in transgenic 
a)

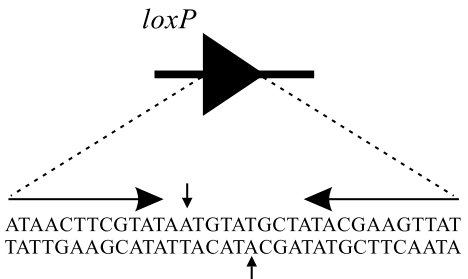

b)

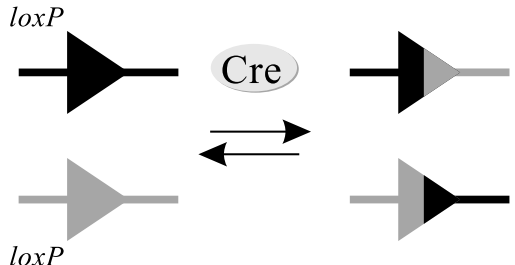

c) Recombination en cis

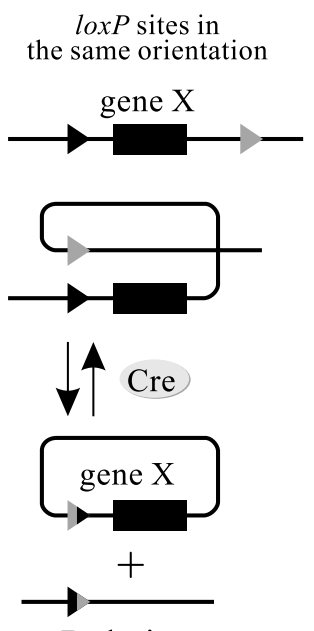

Deletion

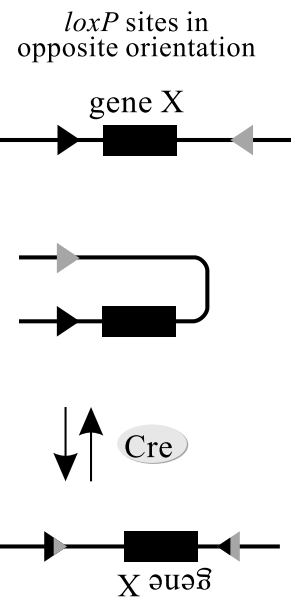

Inversion

\section{d) Recombination in trans}

$1 \operatorname{lox} P$ site in situ

1 loxP site carried by a plasmid

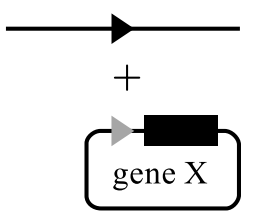

$\downarrow \uparrow$ Cre

gene $\mathrm{X}$

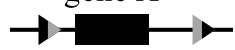

Insertion $\operatorname{lox} P$ sites on two homologous chromosomes

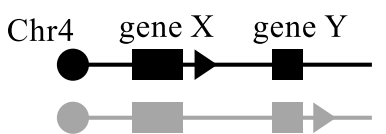

Chr4
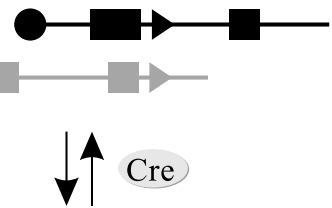

gene $\mathrm{X}$

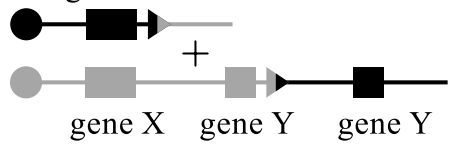

Deletion / Duplication
loxP sites on two different chromosomes

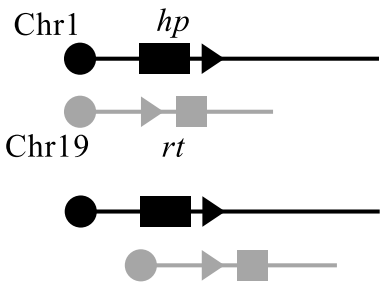

$\downarrow \uparrow$ Cre

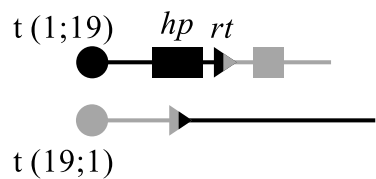

Translocation 
Fig. 4 - The Cre/loxP system and its applications. The lox $P$ site, symbolized by a triangle is a sequence of 34 base pairs composed of palindromic sequences of $13 \mathrm{pb}$ separated by a sequence of $8 \mathrm{pb}(\mathrm{A})$. Cre recombinase specifically recognizes this sequence, provokes the cleavage in DNA (vertical arrows, A) and induces the recombination of DNA between the two loxP sites as illustrated in B. This reaction is reversible. Several types of recombination events can be produced depending on whether the two loxP sites are carried by the same DNA molecule (recombination in cis) or by two different DNA molecules (recombination in trans) and depending on the respective orientation of the two loxP sites (the orientation of a loxP is given by the non-palindromic 8 pb sequence). Recombination in cis (C). If the two loxP sites have the same orientation, the DNA region situated between these sites is deleted during recombination. This type of configuration is used to create "clean" mutations (elimination of the selection cassette, see Fig. 3), conditional mutations (see Fig. 5) and deletions. If the orientation of the two loxP sites is opposed, recombination leads to the inversion of the region comprised between the two sites. Recombination in trans (D). If one loxP site is integrated in the genome and the other is carried by a circular plasmid, there may be an insertion of sequences carried by the plasmid in the integrated loxP site. However, since the insertion is a rare event compared to deletion (i.e., the reverse reaction), this type of event requires the use of mutant loxP sites (see Conclusions/Perspectives). When the $\operatorname{lox} P$ sites are both integrated in the genome, recombination in trans induces chromosomal rearrangements: deletions, duplications or translocations. Such recombination events are rare and have to be selected to be revealed. To do so, one can use truncated and non-functional hp- $l o x P$ and $l o x P$-rt selection cassettes. After recombination between the $l o x P$ sites, and only in this case, a functional hp- lox $P$-rt cassette (the remaining lox $P$ site is situated in an intron) is reconstituted, thus allowing selection of the chromosomal rearrangement desired. Furthermore, the relative orientation of loxP sites compared with the centromeric telomeric axis of the chromosomes is important. Indeed, in the case of wrong relative orientation, recombination will result in the formation of acentric or dicentric chromosomes, which, in view of their great instability, will be eliminated from the cell.

mice. This strategy could therefore be used for the temporal and spatial control of the expression of Cre (Utomo et al. 1999). For various reasons, the conditional mutagenesis strategies that we have briefly described may prove difficult to use. However they are of invaluable interest in thorough gene function analysis and many teams are conducting research to improve the different steps. Two conditions are mandatory to avoid any bias in results and their interpretation: (1) the total cell population in which one wants to measure the impact of the mutation must express protein Cre; (2) expression of protein Cre must be strictly controlled and limited to the population concerned. These conditions are difficult to fulfill, in particular because expression of protein Cre is generally obtained by the creation of conventional transgenic mice (through microinjection into the zygote) in which the transgene is integrated at random; however, it is well established that transgene expression depends on its site of insertion and therefore may be perturbed or even lost. This can be circumvented by inserting, via “'Knock-in' (see above), Cre coding sequences in a gene with specific expression corresponding to the cell types in which the investigator wishes to induce the mutation (Rickert et al. 1997, Harada et al. 1999).

\section{CONCLUSION/PERSPECTIVES}

If we look at the present state of programmed mutagenesis in vivo in the mouse, several reflections come to mind as regards the ways to circumvent the present difficulties and the possible developments.

1) First, it is important to note that among the mammalians studied, programmed modification of the germ line is only accessible in laboratory mice. Indeed, until now, it has been impossible, despite multiple attempts, to isolate ES type cells capable of colonizing the germ line in other laboratory or farm mammals. A special mention should be made about the human species. Indeed, three different groups (Thomson et al. 1998, Shamblott et al. 1998, Reubinoff et al. 2000) have recently reported the isolation of human pluripotent embryonic stem cells. In two cases, these cells were isolated from blastocysts, 


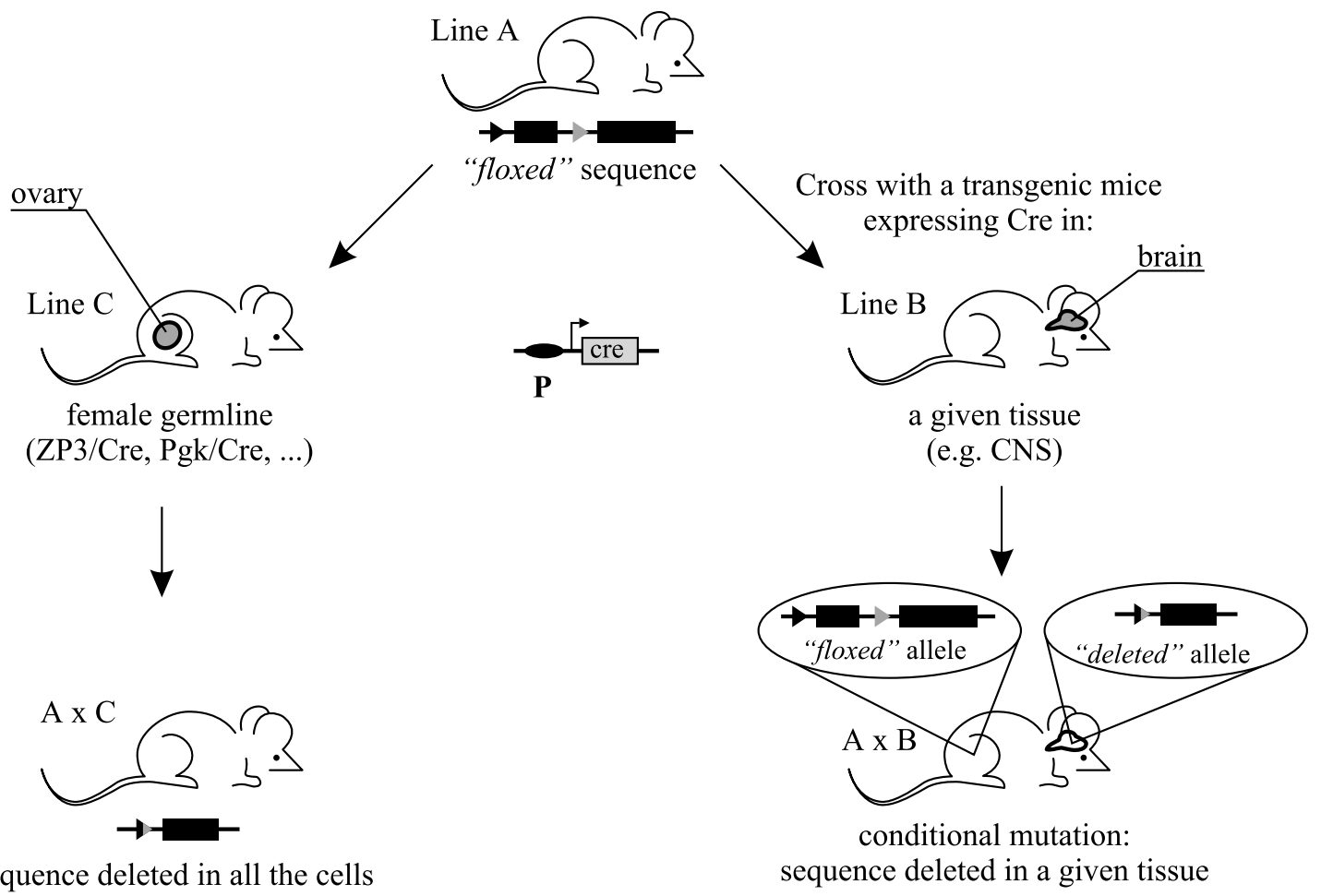

Fig. 5 - The Cre/loxP system in vivo. The Cre/loxP system can be used directly in the mouse. The most common applications of this approach are illustrated in this figure and require the use of two types of mouse. The first mouse (line A), obtained after homologous recombination in the ES cells, carries in its genome a "floxed"' sequence (exons, regulatory sequences, promoter, selection cassette,...). The other is a transgenic mouse expressing the Cre recombination under the control of a given promoter. If this promoter directs the expression of $\mathrm{Cre}$ in the female germ line (strain C), the animals issued from a cross between a female $\mathrm{C}$ and a male $\mathrm{A}$ will carry the deletion in all their cells, the recombination event having taken place at the zygote stage through the recombinase accumulated in the oocyte. If the promoter directs the expression of Cre in one or several cell types (strain B), the animals born from a cross between a mouse $\mathrm{A}$ and a mouse $\mathrm{C}$ will be mosaics: the cell types expressing the recombinase will carry a deleted allele whereas the other cells of the animal will carry a "floxed"' allele. CNS: central nervous system; P: promoter.

in the third case, the pluripotent cells were generated taking a different route in which germ cells from foetal gonads were used as a starting material (these cells are therefore called Embryonic Germ (EG) cells). Although it was not possible to test their ability to contribute to the germ line, the human ES cells share with those of the mouse other key features of embryonic stem cells, i.e., unlimited self-renewal, normal caryotype, ability to differentiate into cell types of the three germ layers. However, there remain several problems to be solved before they can be used in such a versatile way as is the case with mouse ES cells. These difficulties pertain, in particular, to the very limited knowledge of the factor(s) which control and maintain the undifferentiated state and to the fact that they exhibit a poor ability to grow clonally. Despite these limitations, which should be overcome in the near future, the availability of human ES cells opens new and very interesting possibilities both for a better understanding of human embryonic development and for ES cell based therapies (for a review, see Pera et al. 2000).

A recent study illustrates a possible means, 
TABLE IV

Some examples of knock-in.

\begin{tabular}{|c|c|c|c|c|c|}
\hline $\begin{array}{l}\text { Target } \\
\text { gene }\end{array}$ & $\begin{array}{l}\text { Null mutation } \\
\text { phenotype }\end{array}$ & $\begin{array}{l}\text { Cre targeting } \\
\text { method }\end{array}$ & $\begin{array}{l}\text { Tissues eliciting } \\
\text { recombination }\end{array}$ & $\begin{array}{l}\text { Conditional } \\
\text { mutation } \\
\text { phenotype }\end{array}$ & Ref. \\
\hline$A P C$ & $\begin{array}{l}\text { Embryo death } \\
\text { (E 6.5) }\end{array}$ & $\begin{array}{l}\text { Infection by } \\
\text { adenovirus }\end{array}$ & $\begin{array}{l}\text { Colorectal } \\
\text { epithelium } \\
\text { (inoculation site) }\end{array}$ & Intestinal polyps & $\begin{array}{l}\text { Shibata } \\
\text { et al. } \\
1997\end{array}$ \\
\hline$\beta$-catenine & $\begin{array}{l}\text { Embryo death } \\
\text { (E 7.5) }\end{array}$ & $\begin{array}{l}\text { Knock-in } \\
(\text { Ktrl-19) or } \\
\text { Tg }(\text { Fabp })\end{array}$ & $\begin{array}{l}\text { Intestinal } \\
\text { epithelium }\end{array}$ & Intestinal polyps & $\begin{array}{l}\text { Harada } \\
\text { et al. } \\
1999\end{array}$ \\
\hline $\begin{array}{l}I R \text { (insulin } \\
\text { receptor) }\end{array}$ & $\begin{array}{l}\text { Diabetic acid } \\
\text { ketosis } \\
\text { Perinatal lethality }\end{array}$ & $\operatorname{Tg}(\operatorname{Ins})$ & $\begin{array}{l}\beta \text { cells of the } \\
\text { pancreas }\end{array}$ & Type II diabetes & $\begin{array}{l}\text { Kulkarni } \\
\text { et al. } \\
1999\end{array}$ \\
\hline BRCAl & $\begin{array}{l}\text { Embryo death } \\
\text { (E 8.5) }\end{array}$ & $\operatorname{Tg}(W A P)$ & $\begin{array}{l}\text { Epithelium of the } \\
\text { mammary gland }\end{array}$ & $\begin{array}{l}\text { Tumors and } \\
\text { abnormal } \\
\text { development of } \\
\text { the breast gland }\end{array}$ & $\begin{array}{l}\text { Xu et al. } \\
1999\end{array}$ \\
\hline NMDARI & $\begin{array}{l}\text { Prenatal lethality } \\
\text { Multiple CNS } \\
\text { abnormalities }\end{array}$ & $\begin{array}{l}\mathrm{Tg} \\
(\alpha C A M K I I)\end{array}$ & $\begin{array}{l}\text { Hippocampus } \\
\text { (pyramidal cells } \\
\text { of the CA1 } \\
\text { region) }\end{array}$ & $\begin{array}{l}\text { Spatial memory } \\
\text { acquisition } \\
\text { defects }\end{array}$ & $\begin{array}{l}\text { Tsien et } \\
\text { al. } 1996\end{array}$ \\
\hline
\end{tabular}

Tg: transgenic mouse for a fusion gene between the coding sequences of Cre recombination and the regulatory sequences (including the promoter) of the genes indicated (Fabp: fatty acid binding protein; Wap: whey acidic protein; $\alpha$ Ca MKII: ( calcium calmoduline kinase II dependent); Krt1-19:cytokeratine 19; CNS: central nervous system.

though experimentally demanding, to perform programmed genetic modifications in absence of bona fide ES cells; it is based on the advent of methods allowing cloning of several mammalian species by the transfer of nuclei from embryonic and even adult nuclei into oocytes (sheep, cow, mouse and and most recently pig) (for a review, see (Solter 2000). Indeed, McCreath et al. (2000) targeted the ovine $\alpha 1$ (I) procollagen gene in sheep fetal fibroblasts and could reconstitute a whole animal by the transfer of a nucleus carrying the genetic modification into an enucleated oocyte. Despite its fairly low rate of success (about $1 \%$ of the reconstructed embryos give rise to live and apparently normal offspring), these results represent a breakthrough and demonstrate the feasability of obtaining gene targeted animals in mammals by nuclear transfer.

2) We have emphasized the obvious interest of obtaining, via programmed ES cell mutagenesis, mutants for the study of various biological problems. However two other aspects of ES cells should be underlined. The first pertains to the ability of ES cells to undergo differentiation in vitro. Over recent years, a number of teams have tried to develop experimental conditions permitting orientation of this differentiation towards a given lineage (muscle, hematopoietic, nerve cells, etc.) (Brustle et al. 1999, for a review see Keller 1995). Once these 
a)

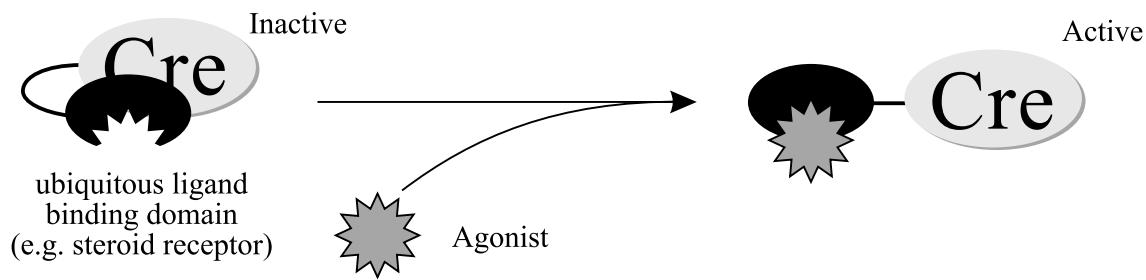

b)

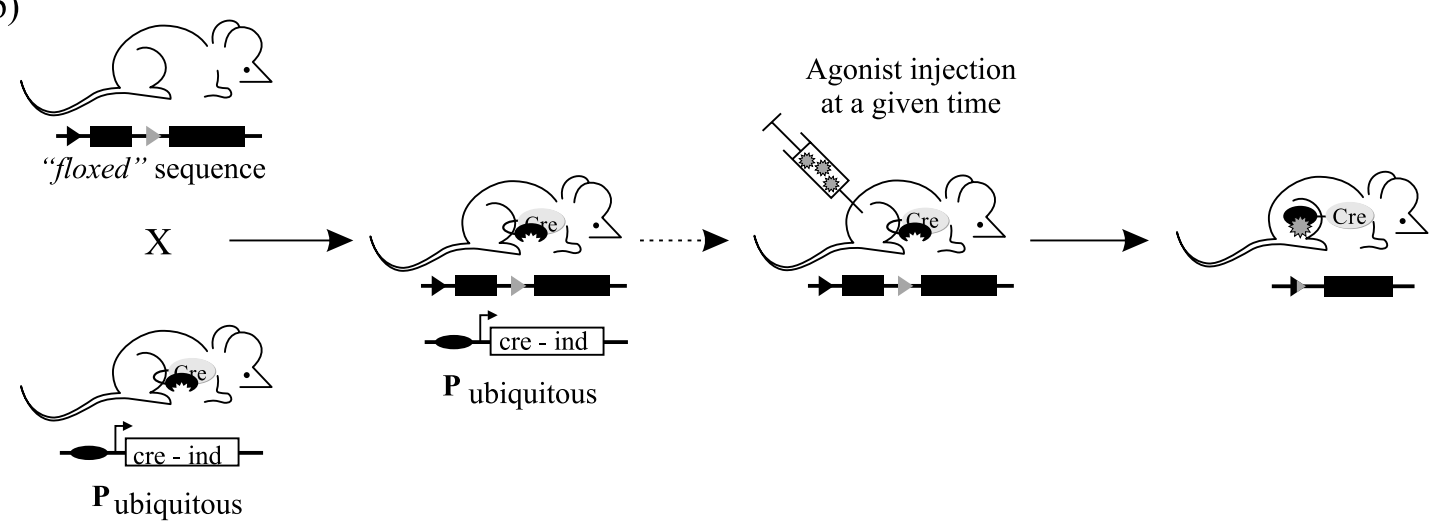

Fig. 6 - The Cre/loxP system and inducible mutations. (A) This strategy relies on the use of a fusion protein between the Cre recombinase and the ligand binding domain of a steroid hormone nuclear receptor. In the absence of a ligand, recombinase activity is null or very weak, whereas in the presence of a ligand it is rapidly induced. The ligand-binding domain is a modified version which presents reduced affinity for the natural ligand (progesterone, estrogen) but increased in the case of synthetic analogs (RU486, tamoxifen). The activity of this inducible Cre recombinase (Cre-ind) is therefore controlled by administration of the agonist. b) This strategy can be applied in vivo, in animals carrying not only a "floxed" sequence but also a transgene coding for Cre-ind controlled by a promoter (ubiquitous here). Deletion of the "floxed"' sequence is dependent on the administration to this mouse of an agonist. It therefore provides a way to control the time of the appearance of a targeted genetic modification. If, instead of an ubiquitous promoter, a specific promoter is used, then the appearance of the modification can be controlled both in terms of time and localization (tissue or cell type).

systems have been developed, introduction in ES cells of the gene mutations eventually implied in a given differentiation pathway and should bring new light on their function. Secondly, certain aspects of the phenotype engendered by a given genetic modification (null mutation in the homozygous state, dominant negative allele) can be further defined by the creation of chimeras between the genetically modified ES cells and wildtype embryos (Rossant et al. 1998). This type of analysis allows, in particular, to determine whether a mutation is cell autonomous or not.

3) From a methodological point of view, de- spite the wide use of programmed mutagenesis in the mouse, it should be noted that it remains difficult and expensive not only in time but also in terms of budget. From this point of view, the development of new scenarios should in the long-term ensure that the creation of mutations is less costly and more efficient. These scenarios profit essentially from the existence of enzymatic systems that play a role in the recombination process. One of them is the Cre/loxP system that has been largely presented above. Thus, it would be valuable to try and take advantage of the integration event catalyzed by the Cre recombinase, resulting in the integration of a circular DNA 
carrying a $\operatorname{lox} P$ site in a genomic location of interest also carrying a $\operatorname{lox} P$ site (Fig. 4D). Normally it is the reverse reaction (intramolecular deletion) that is privileged. However some "tricks" (based on the use of mutant loxP sites) allow to enhance the insertion reaction (Araki et al. 1997). Another approach relies on the observation of robust stimulation of recombination following double-strands DNA breaks. These can be promoted by using a meganuclease, I-SceI, isolated from yeast, which recognizes a specific $18 \mathrm{bp}$ site. Once an allele of a given gene carrying an I-SceI site has been created (by homologous recombination in ES cells), varying genetic modifications could be introduced repeatedly and efficiently by co-transfection of an expression vector for I-SceI, promoting a double-strand break, together with a repair vector permitting the introduction of the desired modification (Donoho et al. 1998, Cohen-Tannoudji et al. 1998). Such approaches may ultimately permit programmed mutagenesis directly in ovo, which would represent an obvious simplification.

4) Despite the interest of targeted mutagenesis that we have underlined in this article, it remains a quite laborious and step by step process: cloning of the gene considered, construction of appropriate vectors, selection and identification of targeted cells and derivation of the corresponding mutant mice. More than 1500 genes have now been processed in this manner, which is a minority compared with the 30 to 40000 genes contained by the genome of the mouse or man. Sequencing programs will provide these genes, till we reach complete sequencing of the mouse genome which should soon happen. There would be great interest in developing tools permitting the mutation of any gene, while circumventing the cloning phase. As far as this is concerned, an approach is being developed, based on a gene trap strategy strategy in ES cells using a trapping vector which in principle traps any gene, whether expressed or not (Zambrowicz et al. 1998). Thus, a library of ES cells is available, carrying tagged genes. However, this approach has its own limitations: the type of mutation is stereotyped (insertion) and insertion of the trapping vector does not lead to total invalidation in all cases. In conclusion, it is clear that homologous recombination in ES cells of the mouse has met its expectations. Creation of widely varying types of mutations, affecting either a gene or whole genomic regions continues to supply invaluable information on the function of genes and the genome in the physiology and biology of the mouse while providing murine models of human diseases. The recent methodological developments, based on the use of proteins that intervene in the recombination process, will obviously widen these possibilities not only qualitatively but also quantitatively.

\section{ACKNOWLEDGEMENTS}

Charles Babinet is directeur de recherche au CNRS, directeur de l'unité de Biologie du Développement de l'Institut Pasteur. Michel Cohen-Tannoudji is chargé de recherche au CNRS.

This article has been adapted, with permission, from a paper originally published in Médecine/ Sciences (2000), 16: 31-42.

\section{RESUMO}

A capacidade de introduzir modificações genéticas na linhagem germinal de organismos complexos tem sido, por muito tempo, uma meta dos estudiosos da biologia do desenvolvimento. Neste aspecto, o camundongo, um modelo favorito de estudo dos mamíferos, é singular. Assim, desde o final dos anos setenta, tem sido possível não só adicionar genes ao genoma do camundongo, como em vários outros organismos complexos, mas, também realizar a substituição e modificação de seus genes. Isto tem sido possível graças a dois rasgos tecnológicos: 1) o isolamento e cultura de células-tronco embrionárias, que têm a capacidade singular de colonizar todos os tecidos de um embrião hospedeiro, inclusive de sua linhagem germinal; 2) o desenvolvimento de métodos que permitem a recombinação homóloga entre um DNA que "ingressa", e sua sequiência cromossomal cognata ("mira" genética - "gene targetting”' Como resultado, tornou-se possível criar camundongos que carreiam mutações nulas em qualquer gene clonado (camundongos “'knock out'), Tal pos- 
sibilidade revolucionou a abordagem genética de quase todos os aspectos da biologia do camundongo. Em anos recentes, o escopo da "mira" genética ampliou-se ainda mais devido ao refinamento da tecnologia de "knock out": outros tipos de modificações genéticas podem agora ser criadas, incluindo mutações sutis (mutações punctiformes, micro-deleções ou inserções, etc) e rearranjos cromossomais tais como grandes deleções, duplicações e translocações. Finalmente, têm sido implementados métodos que permitem a criação de mutações condicionais, permitindo o estudo da função gênica ao longo da vida do animal, quando a inativação do gene acarreta a letalidade embrionária. Neste artigo, apresentamos uma revisão geral dos métodos e situações usadas para a modificação programada do genoma do camundongo e acentuamos seu enorme interesse para o estudo da biologia dos mamíferos.

Palavras-chave: células-tronco embrionárias, genoma, mira genética, camundongos "knock out", mutações condicionais.

\section{REFERENCES}

Acampora D, Avantaggiato V, Tuorto F, Barone P, Perera M, Choo D, Wu D, Corte G and SimeONE A. 1999. Differential transcriptional control as the major molecular event in generating Otx1-/- and Otx2-/- divergent phenotypes. Development 126: 1417-1426.

Araki K, Araki M and Yamamura K. 1997. Targeted integration of DNA using mutant lox sites in embryonic stem cells. Nucleic Acids Res 25: 868-872.

Avery OT, Macleod CM and McCarty M. 1944. Studies on the chemical nature of the substance inducing transformation of pneumococcal types. Induction of transformation by a desoxyribonucleic acid fraction isolated from Pneumococcus type III. J Exp Med 79: 137-158.

Banbury Conference (on Genetic Background in MicE). 1997. Mutant mice and neuroscience: recommendations concerning genetic background. Neuron 19: 755-759.

Baron U, Schnappinger D, Helbl V, Gossen M, Hillen W and Bujard H. 1999. Generation of conditional mutants in higher eukaryotes by switching between the expression of two genes. Proc Nat Acad Sci U S A 96: 1013-1018.

Bode VC. 1984. Ethylnitrosourea mutagenesis and the isolation of mutant alleles for specific genes located in the $\mathrm{T}$ region of mouse chromosome 17. Genetics 108: $457-470$.

Brown SD AND Peters J. 1996. Combining mutagenesis and genomics in the mouse - closing the phenotype gap. Trends Genet 12: 433-435.

Brustle O, Jones KN, Learish RD, Karram K, Choudhary K, Wiestler OD, Duncan ID and McKaY RD. 1999. Embryonic stem cell-derived glial precursors: a source of myelinating transplants. Science 285: 754-756.

CAPeCCHI MR. 1989. Altering the genome by homologous recombination. Science 244: 1288-1292.

Cohen-Tannoudji M and Babinet C. 1998. Beyond 'knock-out' mice: new perspectives for the programmed modification of the mammalian genome. Mol Hum Reprod 4: 929-938.

Cohen-Tannoudi M, Robine S, Choulika A, Pinto D, El Marjou F, Babinet C, Louvard D and JAISSER F. 1998. I-SceI - induced gene replacement at a natural locus in embryonic stem cells. Mol Cell Biol 18: 1444-1448.

Colucci-Guyon E, Portier M-M, Dunia I, Paulin D, Pournin S and Babinet C. 1994. Mice lacking vimentin develop and reproduce without an obvious phenotype. Cell 79: 679-694.

Doetschman T, Gregg RG, Maeda N, Hooper ML, Melton DW, Thompson S And Smithies O. 1987. Targetted correction of a mutant HPRT gene in mouse embryonic stem cells. Nature 330: 576-578.

Donoho G, Jasin M and Berg P. 1998. Analysis of gene targeting and intrachromosomal homologous recombination stimulated by genomic double-strand breaks in mouse embryonic stem cells. Mol Cell Biol 18: 4070-4078

Evans MJ and Kaufman MH. 1981. Establishment in culture of pluripotential cells from mouse embryos. Nature 292: 154-156. 
Feil R, Brocard J, Mascrez B, LeMeur M, Metzger D and Chambon P. 1996. Ligand-activated sitespecific recombination in mice. Proc Natl Acad Sci USA 93: 10887-10890.

Fiering S, Bender MA And Groudine M. 1999. Analysis of mammalian cis-regulatory DNA elements by homologous recombination. Methods Enzymol 306: 42-66.

GARDNer RL And Brook FA. 1997. Reflections on the biology of embryonic stem (ES) cells. Int J Dev Biol 41: 235-243.

Geng Y, Whoriskey W, Park MY, Bronson RT, Medema RH, Li T, Weinberg RA AND Sicinski P. 1999. Rescue of cyclin D1 deficiency by knockin cyclin E. Cell 97: 767-777.

Gossler A, Doetschman T, Korn R, Serfling E And KemLeR R. 1986. Transgenesis by means of blastocyst-derived embryonic stem cell lines. Proc Natl Acad Sci USA 83: 9065-9069.

Gu H, Marth JD, Orban PC, Mossmann H and RaJEWSKY K. 1994. Deletion of a DNA polymerase beta gene segment in $\mathrm{T}$ cells using cell type-specific gene targeting. Science 265: 103-106.

Hanks M, Wurst W, Anson-Cartwright L, AuerBACH AB AND JOYNER AL. 1995. Rescue of the En-1 mutant phenotype by replacement of En-1 with En-2. Science 269: 679-682.

Hanks MC, Loomis CA, Harris E, Tong CX, AnsonCartwright L, Auerbach A and Joyner A. 1998. Drosophila engrailed can substitute for mouse Engrailed1 function in mid-hindbrain, but not limb development. Development 125: 4521-4530.

Harada N, Tamai Y, Ishikawa T, Sauer B, Takaku K, Oshima M and TAKeto MM. 1999. Intestinal polyposis in mice with a dominant stable mutation of the beta-catenin gene. EMBO J 18: 5931-5942.

Herault Y, Rassoulzadegan M, Cuzin F and Duboule D. 1998. Engineering chromosomes in mice through targeted meiotic recombination (TAMERE). Nat Genet 20: 381-384.

Horan GS, Ramirez SR, Featherstone MS, WolGemuth DJ, Bradley A AND Behringer RR. 1995. Compound mutants for the paralogous hoxa-
4, hoxb-4, and hoxd-4 genes show more complete homeotic transformations and a dose-dependent increase in the number of vertebrae transformed. Genes Dev 9: 1667-1677.

Justice MJ, Zheng B, Woychik RP AND Bradley A. 1997. Using targeted large deletions and high-efficiency N-ethyl-N- nitrosourea mutagenesis for functional analyses of the mammalian genome. Methods 13: 423-436.

Kellendonk C, Tronche F, Monaghan AP, Angrand PO, Stewart F and Schutz G. 1996. Regulation of Cre recombinase activity by the synthetic steroid RU 486. Nucleic Acids Res 24: 1404-1411.

KELLER GM. 1995. In vitro differentiation of embryonic stem cells. Curr Opin Cell Biol 7: 862-869.

Kerem B, Rommens JM, Buchanan JA, Markiewicz D, Cox TK, Chakravarti A, Buchwald M and Tsui LC. 1989. Identification of the cystic fibrosis gene: genetic analysis. Science 245: 1073-1080.

Kilby NJ, Snaith MR and Murray JAH. 1993. Sitespecific recombinases: tools for genome engineering. Trends Genet 9: 413-421.

Kulkarni RN, Bruning JC, Winnay JN, Postic C, Magnuson MA and Kahn CR. 1999. Tissuespecific knockout of the insulin receptor in pancreatic beta cells creates an insulin secretory defect similar to that in type 2 diabetes. Cell 96: 329-339.

MARTIN GR. 1981. Isolation of a pluripotent cell line from early mouse embryos cultured in medium conditioned by teratocarcinoma stem cells. Proc Natl Acad Sci U S A 78: 7634-7638.

McCreath KJ, Howcroft J, Campbell KHS, Colman A, Schnieke AE And Kind AJ. 2000. Production of gene-targeted sheep by nuclear transfer from cultured somatic cells. Nature 405: 1066-1069.

Meyers EN, Lewandoski M And Martin GR. 1998. An Fgf-8 mutant allelic series generated by Cre- and Flp-mediated recombination. Nature Genetics 18: 136-141.

Moore RC, Hope J, McBride PA, McConnell I, SelfRIDGe J, Melton DW and Manson JC. 1998. Mice with gene targetted prion protein alterations whow that Prnp, Sinc and Prni are congruent. Nat Genet 
18: $118-124$.

Pera MF, Reubinoff B and Trounson A. 2000. Human embryonic stem cells. J Cell Sci 113: 5-10.

Ramirez-Solis R, Liu P And Bradley A. 1995. Chromosome engineering in mice. Nature 378: 720-724.

Reubinoff BE, Pera MF, Fong C-Y, Trounson A and Bongso A. 2000. Embryonic stem cell lines from human blastocysts: somatic differentiation in vitro. Nat Biotechnol 18: 399-404.

Rickert RC, Roes J AND RAJEwsky K. 1997. B lymphocyte-specific, Cre-mediated mutagenesis in mice. Nucleic Acids Res 25: 1317-1318.

Robertson E, Bradley A, Kuehn M and Evans M. 1986. Germ-line transmission of genes introduced into cultured pluripotential cells by retroviral vector. Nature 323: 445-448.

Rossant J, Spence A and Rossant J. 1998. Chimeras and mosaics in mouse mutant analysis. Trends Genet 14: 358-363.

Rudnicki MA and JaEnisch R. 1995. The MyoD family of transcription factors and skeletal myogenesis. Bioessays 17: 203-209.

SAGA Y. 1998. Genetic rescue of segmentation defect in MesP2-deficient mice by MesP1 gene replacement. Mech Dev 75: 53-66.

SAUER B. 1998. Inducible gene targeting in mice using the Cre/lox system. Methods 14: 381-392.

SAuer B And Henderson N. 1988. Site-specific DNA recombination in mammalian cells by the Cre recombinase of bacteriophage P1. Proc Natl Acad Sci USA 85: $5166-5170$.

Schneider-Maunoury S, Topilko P, Seitandou T, Levi G, Cohen-Tannoudji M, Pournin S, BabiNET C ANd Charnay P. 1993. Disruption of Krox20 results in alteration of rhombomeres 3 and 5 in the developing hindbrain. Cell 75: 1199-1214.

Shamblott MJ, Axelman J, Wang S, Lilleberg SL, Person C and Sands AT. 1998. Derivation of pluripotent stem cells from cultured human primordial germ cells. Proc Natl Acad Sci USA 95: 13726-13731.
Shibata H, Toyama K, Shioya H, Ito M, Hirota M, Hasegawa S, Matsumoto H, Takano H, Akiyama T, Toyoshima K, Kanamaru R, Kanegae Y, Saito I, Nakamura Y, Shiba K AND NoDA T. 1997. Rapid colorectal adenoma formation initiated by conditional targeting of the Apc gene. Science 278: 120-123.

Smithies O. 1993. Animal models of human genetic diseases. Trends Genet 9: 112-116.

Smithies O, Gregg RG, Boggs SS, Koralewski MA AND KUChERLAPATI RS. 1985. Insertion of DNA sequences into the human chromosomal beta-globin locus by homologous recombination. Nature 317: 230-234.

Solter D. 2000. Mammalian cloning. Nat Rev Genet 1: 199-207.

Suda Y, Nakabayashi J, Matsuo I and Aizawa S. 1999. Functional equivalency between Otx2 and Otx1 in development of the rostral head. Development 126: 743-757.

Tajbakhsh S, Rocancourt D and Buckingham M. 1996. Muscle progenitor cells failing to respond to positional cues adopt non-myogenic fates in myf-5 null mice. Nature, 384: 266-70.

TBASE. 2001. The Transgenic/Targeted Mutation Database, http://tbase.jax.org/.

Thomas KR and CAPecchi MR. 1987. Site-directed mutagenesis by gene targeting in mouse embryo-derived stem cells. Cell 51: 503-512.

Thomson JA, Itskovitz-Eldor J, Shapiro SS, Waknitz MA, Swiergiel JJ, Marshall VS and JONES JM. 1998. Embryonic stem cell lines derived from human blastocysts. Science 282: 1145-1147.

Tsien JZ, Huerta PT and Tonegawa S. 1996. The essential role of hippocampal CA1 NMDA receptordependent synaptic plasticity in spatial memory. Cell 87: $1327-1338$.

Utomo AR, Nikitin AY and Lee WH. 1999. Temporal, spatial, and cell type-specific control of Cremediated DNA recombination in transgenic mice. Nat Biotechnol; 17: 1091-1096.

Vidal F, Sage J, Cuzin F and Rassoulzadegan M. 
1998. Cre expression in primary spermatocytes: a tool for genetic engineering of the germ line. Mol Reprod Dev 51: 274-280.

WANG Y AND JAENisch R. 1997. Myogenin can substitute for Myf5 in promoting myogenesis but less efficiently. Development 124: 2507-2513.

WoNG EA AND CAPECCHI MR. 1986. Analysis of homologous recombination in cultured mammalian cells in transient expression and stable transformation assays. Somat Cell Mol Genet 12: 63-72.

Xu X, Wagner KU, Larson D, Weaver Z, Li C, Ried T, Hennighausen L, Wynshaw-Boris A and Deng CX. 1999. Conditional mutation of Brcal in mammary epithelial cells results in blunted ductal morphogenesis and tumour formation. Nat Genet 22: $37-43$.
You Y, Bergstrom R, Klemm M, Lederman B, NelSON H, Ticknor C, Jaenisch R AND Schimenti J. 1997. Chromosomal deletion complexes in mice by radiation of embryonic stem cells. Nat Genet 15: 285-288.

Zambrowicz BP, Friedrich GA, Buxton EC, Lilleberg SL, Person C and Sands AT. 1998. Disruption and sequence identification of 2,000 genes in mouse embryonic stem cells. Nature 392: 608-611. 